\title{
Zeta-potentials of Oxygen and Nitrogen Enriched Activated Carbons for Removal of Copper Ion
}

\author{
Kwan-Ho Park ${ }^{1}$, Chang-Ho Lee ${ }^{1}$, Seung-Kon Ryu ${ }^{1, \wedge}$ and Xiaoping Yang ${ }^{2}$ \\ ${ }^{1}$ Departmentl of Chemical Engineering, Chungnam National University, Daejeon 305-764, Korea \\ ${ }^{2}$ The Key Laboratory of Beijing City on Preparation and Processing of Novel Polymer Materials, \\ Beijing University of Chemical Technology, Beijing 100029, PR China \\ ‘e-mail: skryu@cnu.ac.kr \\ (Received September 3, 2007; Accepted December 17, 2007)
}

\begin{abstract}
The oxygen and nitrogen enriched activated carbons were obtained from modification of commercial activated carbon by using nitric acid, sodium hydroxide and urea. Zeta-potentials of modified activated carbons were investigated in relation to copper ion adsorption. The structural properties of modified activated carbons were not so much changed, but the zeta-potentials and isoelectric points were considerably changed. The zeta-potential of nitric acid modified activated carbon was the most negative than other activated carbons in the entire $\mathrm{pH}$ region, and the $\mathrm{pH}_{\mathrm{IEP}}$ was shifted from $\mathrm{pH} 4.8$ to 2.6, resulted in the largest copper ion adsorption capacities compare with other activated carbons in the range of $\mathrm{pH} 3 \sim 6.5$. In case of urea modified activated carbon, copper ion adsorption was larger than that of the as-received activated carbon from $\mathrm{pH} 2$ to $\mathrm{pH} 6.5$ even though the $\mathrm{pH} \mathrm{H}_{\mathrm{IEP}}$ was shifted to $\mathrm{pH} 6.0$, it was due to the coordination process operated between nitrogen functional groups and copper ion. The adsorption capacity of copper ion was much influenced by zeta-potential and $\mathrm{pH}_{\mathrm{IEP}}$ of carbon adsorbent.
\end{abstract}

Keywords : Zeta-potential, Activated carbon, Copper ion adsorption

\section{Introduction}

Adsorption of metal ions on activated carbon (AC) from aqueous solution is depending on the surface chemistry and $\mathrm{pH}$ of solution. Surface chemistry of carbon materials was influenced by acidic, basic or neutral functional groups. Many researchers studied oxygen and nitrogen surface functional groups for removal of metal ions [1-8].

Various oxidizers have been used to improve the oxygen functional groups on carbon surface. Among the oxidizers, nitric acid has been the most widely used to increase the total acidity in wet oxidation treatments [1-7]. Most process for improving nitrogen functional groups on carbon surface has been limited in ammonia treatment [7, 8], but another chemical was needed because the ammonia has toxicity. Adib et al. [9] reported that amides, $\mathrm{NH}$ and $\mathrm{NH}_{2}$ or $\mathrm{NH}_{4}^{+}$species were developed on the surface of $\mathrm{AC}$ by impregnation of $\mathrm{AC}$ in urea solution, and then heat treated it up to $450^{\circ} \mathrm{C}$ in $\mathrm{N}_{2}$ surrounding. This AC was very effective in removal of gaseous adsorbates. These oxygen and nitrogen functional groups of $\mathrm{AC}$ are protonated in solution and the $\mathrm{AC}$ surface is being charged negatively or positively. The chemical adsorption is being operated between these charged surface and metal ion. Therefore, measuring the surface charge of carbon is important in metal adsorption.

One of useful methods to measure the surface charge of solid is the zeta-potential measurement. Many researchers have measured the zeta-potentials and isoelectric point $\left(\mathrm{pH}_{\mathrm{IEP}}\right)$ to characterize carbon materials $[6,10-16]$, however only a few studies have mentioned in relation to the removal of metal ions from aqueous solution.

In this work, zeta-potentials of oxygen and nitrogen enriched ACs were studied in relation to removal of copper ion from aqueous solution. To obtained the purpose; i) commercial AC was surface modified by impregnation in nitric acid $\left(\mathrm{HNO}_{3}\right)$, sodium hydroxide $(\mathrm{NaOH})$ and urea $\left(\mathrm{CO}\left(\mathrm{NH}_{2}\right)_{2}\right)$ to enrich the oxygen, and nitrogen functional groups, ii) characterization of modified ACs was performed by using nitrogen adsorption, acid-base neutralization titration techniques, elemental analysis, and zeta-potential measurements, and iii) the $\mathrm{pH}-$ dependent adsorption of copper ion on modified ACs were carried out to investigate the effect of zeta-potential.

\section{Experimental}

\subsection{Modification of $A C$}

Coconut-based commercial AC (Hanil Green Tech. Co., Korea) was used in this study. Before the modification, the $\mathrm{AC}$ was washed with distilled water and dried at $110^{\circ} \mathrm{C}$ for $24 \mathrm{~h}$ and denoted as-received R-AC. A part of R-AC was 
Table 1. Modification conditions of ACs

\begin{tabular}{cccc}
\hline $\mathrm{AC}$ & Chemicals & Temperature $\left({ }^{\circ} \mathrm{C}\right)$ & Time $(\mathrm{h})$ \\
\hline $\begin{array}{c}\mathrm{R}-\mathrm{AC} \\
\text { (as-received) }\end{array}$ & - & - & - \\
$\begin{array}{c}\mathrm{A}-\mathrm{AC} \\
\text { (acid modified) }\end{array}$ & $1 \mathrm{M} \mathrm{HNO}_{3}$ & 80 & 2 \\
$\begin{array}{c}\mathrm{B}-\mathrm{AC} \\
\text { (base modified) } \\
\mathrm{U}-\mathrm{AC}\end{array}$ & $1 \mathrm{M} \mathrm{NaOH}$ & 80 & 2 \\
$\begin{array}{c}1 \mathrm{M} \\
\text { (urea modified) } \\
\mathrm{H}-\mathrm{AC}\end{array}$ & $\mathrm{CO}\left(\mathrm{NH}_{2}\right)_{2}$ & $25 / 450$ & 2 \\
(annealing of A-AC) & - & $1000 / \mathrm{N}_{2}$ & 2 \\
\hline
\end{tabular}

modified with $1 \mathrm{M} \mathrm{HNO}_{3}$ and $1 \mathrm{M} \mathrm{NaOH}$ solution $(1 \mathrm{~g}$ of carbon $/ 10 \mathrm{ml}$ of solution) at $80^{\circ} \mathrm{C}$ for $2 \mathrm{~h}$. The modified ACs were then washed with distilled water until the $\mathrm{pH}$ became constant and dried at $110^{\circ} \mathrm{C}$ for $24 \mathrm{~h}$. The $\mathrm{HNO}_{3}$ and $\mathrm{NaOH}$ modified ACs were denoted as A-AC and B-AC, respectively. In order to prepare the nitrogen enriched $\mathrm{AC}$, a part of $\mathrm{R}-\mathrm{AC}$ was impregnated with $1 \mathrm{M} \mathrm{CO}\left(\mathrm{NH}_{2}\right)_{2}$ solution ( $1 \mathrm{~g}$ of carbon/ $10 \mathrm{ml}$ solution) at room temperature for $2 \mathrm{~h}$, and then annealing was applied in quartz tube: the furnace temperature was raised up to $450^{\circ} \mathrm{C}$ at $10^{\circ} \mathrm{C} / \mathrm{min}$ in $\mathrm{N}_{2}$, and maintained for $1 \mathrm{~h}$, then cooled down to room temperature, which was denoted as U-AC. H-AC was prepared by annealing of A-AC at $1000^{\circ} \mathrm{C}$ in $\mathrm{N}_{2}$ to remove the surface functional groups. Table 1 shows the modification conditions of ACs.

\subsection{Characterization of modified ACs}

Structural properties were measured by using a surface area analyzer (Micromeritics ASAP 2010) from $\mathrm{N}_{2}$ adsorption at $77 \mathrm{~K}$. Elemental analysis was carried out by using EA1110 (CE instrument). Surface functional groups of each modified activated carbons were measured by Boehm method. Zetapotential was measured by using zeta-potential analyzer (Otasuka Electronic Co. ELS-6000). Approximately $50 \mathrm{mg}$ of $\mathrm{AC}$ was dispersed in $1 l$ of $\mathrm{NaCl}$ solution (electrolyte) to ensure ionic strength. In order to obtain $\mathrm{CO}_{2}$-free $\mathrm{NaCl}$ solution, $\mathrm{N}_{2}$ was bubbled through $\mathrm{NaCl}$ solution until the $\mathrm{pH}$ of the solution became 7.0. The $\mathrm{pH}$ of solution was adjusted by adding either $0.1 \mathrm{M} \mathrm{HCl}$ or $0.1 \mathrm{M} \mathrm{NaOH}$ followed by agitation at $200 \mathrm{rpm}$ for $24 \mathrm{~h}$ at $20^{\circ} \mathrm{C}$ to make a equilibrium.

\subsection{Copper ion adsorption}

Adsorptions of copper ion on as-received and modified ACs were performed by changing the solution $\mathrm{pH}$. The copper solution was prepared by mixing $1 \mathrm{mM} \mathrm{CuCl}_{2}$ under $\mathrm{N}_{2}$ pursing. The $\mathrm{pH}$ of solution was adjusted by using $0.1 \mathrm{M}$ $\mathrm{HCl}$ and $0.1 \mathrm{M} \mathrm{NaOH}$. Then, $1 \mathrm{~g}$ of $\mathrm{AC}$ was added to 100 $\mathrm{mL}$ of the solution and agitated at $200 \mathrm{rpm}$ for $24 \mathrm{~h}$ at $20^{\circ} \mathrm{C}$. The copper ion solution was filtered with microsyringe filter and the concentration of copper ion was measured by using

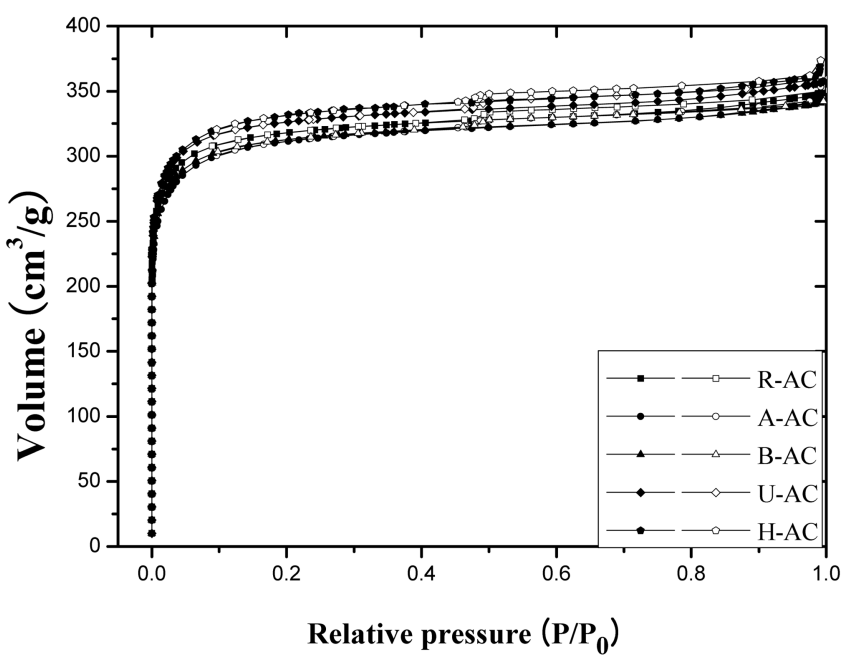

Fig. 1. Nitrogen adsorption isotherms of modified ACs. ( solid $=$ adsorption; open $=$ desorption $)$

inductively coupled plasma (ICP) atomic emission spectrometer (TJA, Atomscan25, USA). The amounts of adsorbed copper ion on AC were determined by the difference of the copper ion concentrations before and after adsorption.

\section{Results and discussion}

\subsection{Textural properties of $A C s$}

Nitrogen adsorption isotherms and structural properties of modified ACs were shown in Fig. 1 and summarized in Table 2. All the isotherms of modified ACs were type I showing that pores developed were micropores. The specific surface areas of modified ACs have shown only a little change within $3 \%$. Wang et al. [4] reported that the surface area of the AC increased by acid and base treatment. On the other hand, Shim et al. [1] and Adib et al. [9] reported that some of the micropores were blocked by functional groups introduced by the chemical modification, resulted in the decrease of surface area as welll as micropore volume. The appearance of hysteresis loops in the adsorption isotherms were due to the existence of some mesopores and slit-shaped pores of ACs.

\subsection{Surface chemical analysis of ACs}

The changes of the surface acidity and basicity of modified ACs were summarized in Table 3. The total acidity increased about 4 times by $\mathrm{HNO}_{3}$ treatment, especially lactone groups increased about 12 times, while total basicity decreased 34\%. For B-AC, total acidity decreased about $60 \%$, but lactone groups increased 2.4 times than that of RAC. Chen et al. [3] also reported that $\mathrm{HNO}_{3}$ treatment generated a large amount of oxygen containing functional groups, especially the $\mathrm{NaOH}$ treatment changed carbonyl 
Table 2. Structural properties of modified ACs

\begin{tabular}{ccccc}
\hline $\mathrm{AC}$ & $\mathrm{S}_{\mathrm{BET}}\left(\mathrm{m}^{2} / \mathrm{g}\right)$ & $\mathrm{S}_{\text {micro }}\left(\mathrm{m}^{2} / \mathrm{g}\right)$ & $\mathrm{V}_{\mathrm{t}}\left(\mathrm{cm}^{3} / \mathrm{g}\right)$ & $\mathrm{D}_{\text {pore }}(\AA)$ \\
\hline $\mathrm{R}-\mathrm{AC}$ & 1247 & 1219 & 0.54 & 17.39 \\
$\mathrm{~A}-\mathrm{AC}$ & 1198 & 1169 & 0.55 & 18.25 \\
$\mathrm{~B}-\mathrm{AC}$ & 1217 & 1191 & 0.53 & 17.39 \\
$\mathrm{U}-\mathrm{AC}$ & 1277 & 1248 & 0.56 & 17.46 \\
$\mathrm{H}-\mathrm{AC}$ & 1283 & 1255 & 0.56 & 17.46 \\
\hline
\end{tabular}

Table 3. Surface acidic and basic contents of modified ACs

\begin{tabular}{cccccc}
\hline & Phenol & Lactone & Carboxyl & $\begin{array}{c}\text { Total } \\
\text { acidity }\end{array}$ & $\begin{array}{c}\text { Total } \\
\text { basicity }\end{array}$ \\
\hline R-AC & 0.19 & 0.05 & 0.15 & 0.39 & 0.35 \\
A-AC & 0.55 & 0.61 & 0.40 & 1.56 & 0.23 \\
B-AC & 0.02 & 0.12 & 0.01 & 0.15 & 0.53 \\
U-AC & 0.12 & 0.04 & 0.07 & 0.23 & 0.57 \\
H-AC & 0.01 & $\mathrm{~N}$ & $\mathrm{~N}$ & 0.01 & 0.52 \\
\hline
\end{tabular}

Table 4. Elemental analysis of modified ACs

\begin{tabular}{cccccc}
\hline & $\mathrm{C}(\mathrm{wt} \%)$ & $\mathrm{H}(\mathrm{wt} \%)$ & $\mathrm{N}(\mathrm{wt} \%)$ & $\mathrm{O}^{\mathrm{a}}(\mathrm{wt} \%)$ & $\mathrm{O} / \mathrm{C}$ \\
\hline $\mathrm{R}-\mathrm{AC}$ & 86.04 & 1.31 & 0.20 & 11.45 & 0.13 \\
$\mathrm{~A}-\mathrm{AC}$ & 77.30 & 3.10 & 0.63 & 18.97 & 0.25 \\
$\mathrm{~B}-\mathrm{AC}$ & 87.55 & 2.14 & 0.17 & 10.14 & 0.12 \\
$\mathrm{U}-\mathrm{AC}$ & 87.12 & 1.17 & 2.04 & 9.67 & 0.11 \\
$\mathrm{H}-\mathrm{AC}$ & 93.45 & 1.19 & 0.20 & 5.16 & 0.06 \\
\hline
\end{tabular}

a: obtained by difference

and carboxyl groups to lactone groups instead of new functional groups generation.

When the $\mathrm{AC}$ was modified by impregnation with $\mathrm{CO}\left(\mathrm{NH}_{2}\right)_{2}$ and heat treated up to $450^{\circ} \mathrm{C}$, the acidity decreased about $40 \%$ and basicity increased about $68 \%$. Adib et al. [9] reported that basic nitrogen functional groups such as $-\mathrm{NH}$, $-\mathrm{NH}_{2},-\mathrm{NH}_{4}^{+}$were enhanced by $\mathrm{CO}\left(\mathrm{NH}_{2}\right)_{2}$ treatment.

Elemental analysis of the modified ACs was summarized in Table 4. R-AC has about $11 \%$ oxygen whereas A-AC contains $66 \%$ higher amounts of oxygen than that of R-AC. However, the oxygen contents of other three ACs decreased due to the removal of acidic oxygen functional groups.

\subsection{Zeta-potentials of ACs}

Zeta-potential was influenced by solution $\mathrm{pH}$ and electrolyte concentration. Therefore, zeta-potentials of R-AC at different $\mathrm{NaCl}$ (electrolyte) concentration were investigated and the results were shown in Fig. 2. The $\mathrm{pH}_{\mathrm{IEP}}$ was shifted to acidic region and zeta-potentials was also lowered by decrease of ionic strength.

Zeta-potentials of modified ACs were shown in Fig. 3. The zeta-potential became more negative as the $\mathrm{pH}$ value increased because of the deposition of more $\mathrm{OH}^{-}$on the surface of ACs [17]. The A-AC showed the most negative zeta-potentials than others over entire $\mathrm{pH}$ region and the $\mathrm{pH}_{\text {IEP }}$ was shifted from $\mathrm{pH} 4.8$ to 2.6. Similar observations

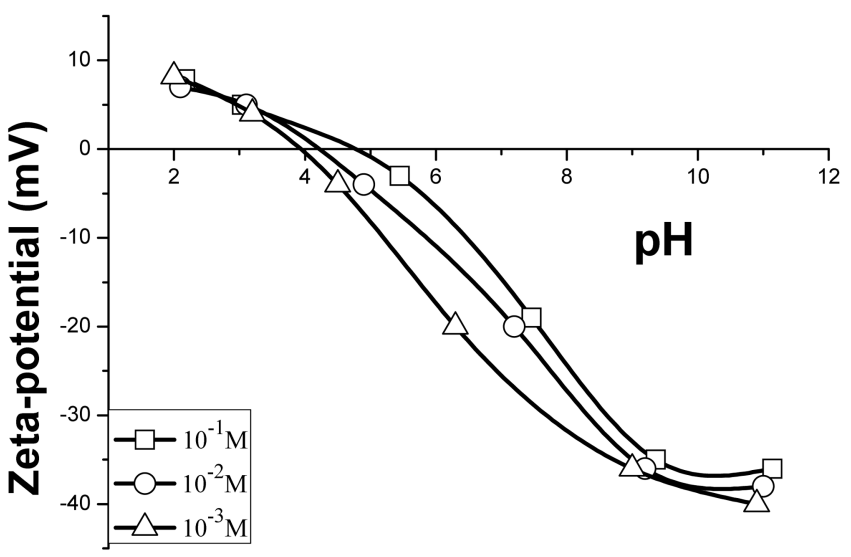

Fig. 2. Zeta-potentials of as-received $\mathrm{AC}$ in $10^{-1} \sim 10^{-3} \mathrm{M} \mathrm{NaCl}$ solution.

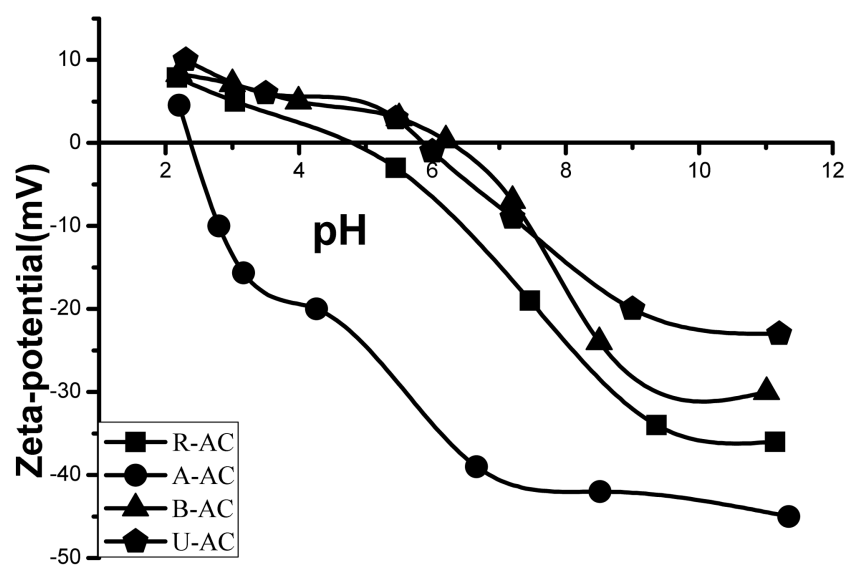

Fig. 3. Zeta-potentials of modified ACs in $10^{-1} \mathrm{M} \mathrm{NaCl}$ solution.

for zeta-potential curves of $\mathrm{HNO}_{3}$ treated carbons were reported in literatures [10-12]. It was due to the increase of negatively charged site on carbon surface by deprotonation of produced strong acidic functional groups such as carboxyl group. Harry et al. [18] reported that deprotonation of carboxyl group mainly occurred in the range from $\mathrm{pH} 2$ to 6 , so the zeta potential of electrochemically oxidized activated carbon fiber steeply increased as the increase of $\mathrm{pH}$, then the zeta-potential curve was plateau above $\mathrm{pH} 6$, and the $\mathrm{pH}_{\mathrm{IEP}}$ was shifted from $\mathrm{pH} 3$ to $\mathrm{pH}$ 1.2. Because the amount of carboxyl group decreased, zeta-potentials of B$\mathrm{AC}$ showed less negatively charged than R-AC and the $\mathrm{pH}_{\mathrm{IEP}}$ shifted to $\mathrm{pH} 6.3$ in spite of the increase of lactone group. The $\mathrm{pH}_{\mathrm{IEP}}$ of the U-AC was shifted to $\mathrm{pH} 6.0$ due to the decrease of acidity and the increase of basicity. The zetapotential and $\mathrm{pH}_{\mathrm{IEP}}$ of the U-AC compared with the R-AC were not much changed, because the nitrogen-containging groups (amides, $\mathrm{NH}$ and $\mathrm{NH}_{2}$ or $\mathrm{NH}_{4}^{+}$species) were behaved as either bases or strong(carboxylic) or weak(phenols) acids, and they are able to behave weak acidic groups [9].

If oxygen functional groups were removed, what will be 


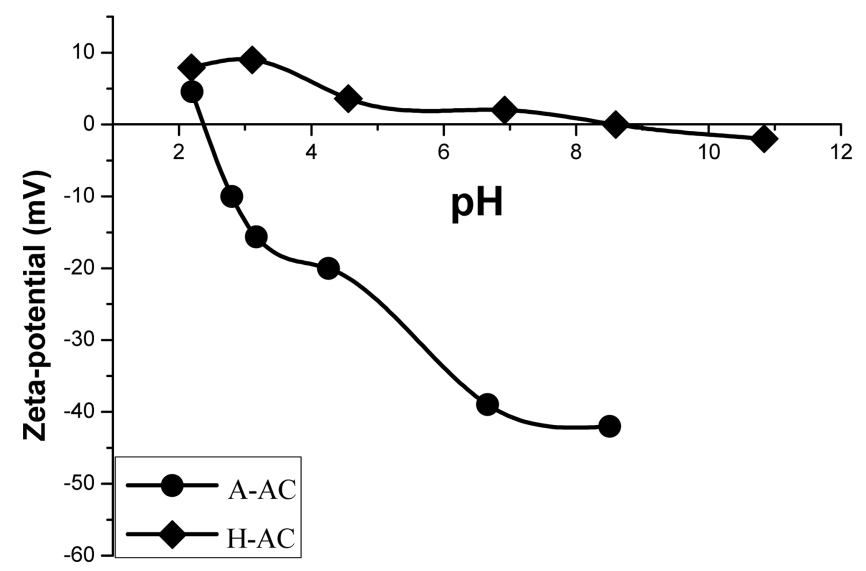

Fig. 4. Zeta-potentials of surface functional groups removed AC in $10^{-1} \mathrm{M} \mathrm{NaCl}$ solution.

happened to zeta-potential. The results were shown in Fig. 4. Heat treated $\mathrm{AC}$ was changed to more basic, so the $\mathrm{pH}_{\mathrm{IEP}}$ of $\mathrm{H}-\mathrm{AC}$ shifted from acid $(\mathrm{pH} 2.5)$ to base $(\mathrm{pH} \mathrm{8.6)}$, but the zeta-potentials get close to zero over the entire $\mathrm{pH}$ region. Yanagisawa et al. [14] reported very similar results that the zeta-potentials of $\mathrm{AC}$ were closed to zero over the entire $\mathrm{pH}$ region when the $\mathrm{AC}$ was heat treated at $1800^{\circ} \mathrm{C}$, because there was a correspondence between the acidic functional group amount and the zeta-potential value, and the surface functional groups were almost decomposed above $1500^{\circ} \mathrm{C}$.

The changes of $\mathrm{pH}_{\mathrm{IEP}}$ in relation to the amount of carboxyl group which was strong acid were shown in Fig 5. The $\mathrm{pH}_{\mathrm{IEP}} \mathrm{S}$ were shifted to more acidic as the increase of the amount of carboxyl group.

\subsection{Copper ion adsorption}

The copper ion adsorption capacities of the modified ACs were shown as a function of the initial (before adsorption)

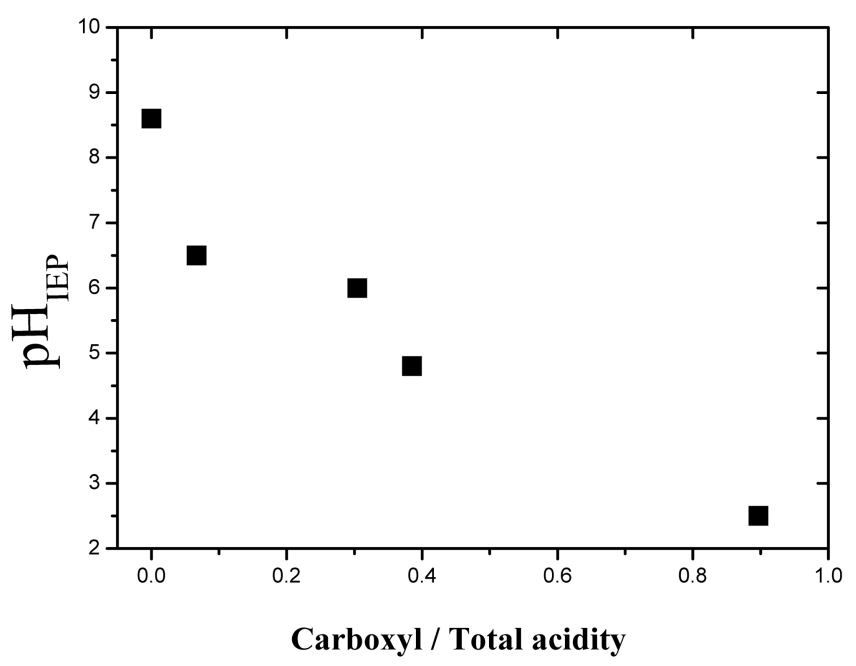

Fig. 5. The $\mathrm{pH}_{\mathrm{IEP}}$ changes as a function of carboxyl/total acidity.

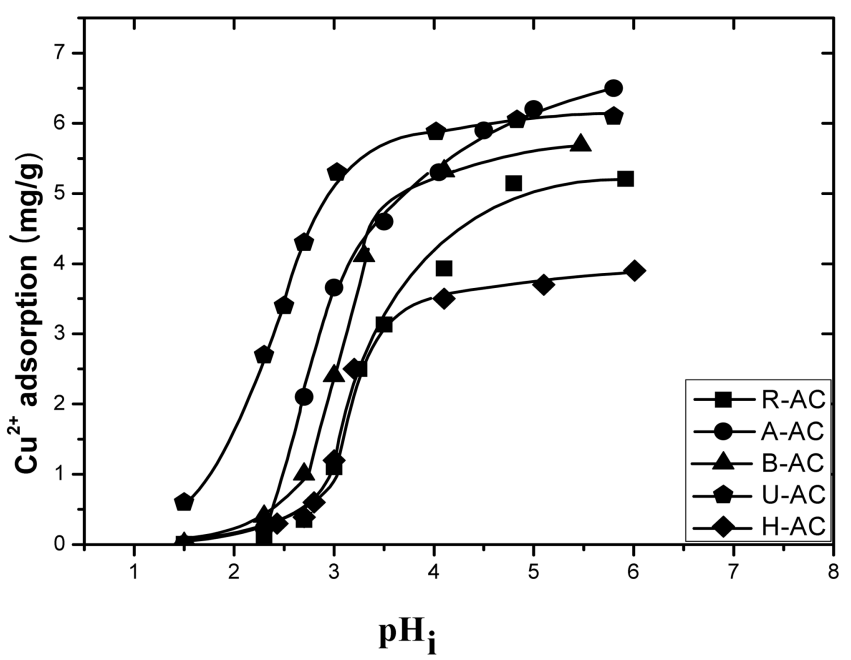

Fig. 6. Adsorption of copper ion as a function of $\mathrm{pH}_{\mathrm{i}}$ on modified ACs.

$\mathrm{pH}$ in Fig. 6. The adsorption capacities of copper ion increased as the increase of initial $\mathrm{pH}$ from 1.5 to 6 . Fig. 7 shows the changes of solution $\mathrm{pH}$ before and after adsorption. The final (after adsorption) $\mathrm{pH}$ was much higher than the initial $\mathrm{pH}$ (except for A-AC). In case of A-AC, the final $\mathrm{pH}$ was not so much changed compared with the initial $\mathrm{pH}$ due to the acidic surface of A-AC. But for other ACs which have basic surface, the final $\mathrm{pH}$ was much higher than the initial $\mathrm{pH}$ because of the strong adsorption of hydrogen ions on ACs [3]. These $\mathrm{pH}$ changes can be influence the copper ion adsorption capacity because of the competitive adsorption of hydrogen ion with copper ion in low $\mathrm{pH}$ region, in addition the zeta-potential measured after equilibrium for $24 \mathrm{~h}$. Therefore the copper ion adsorption capacities of the modified ACs were shown as a function of the final

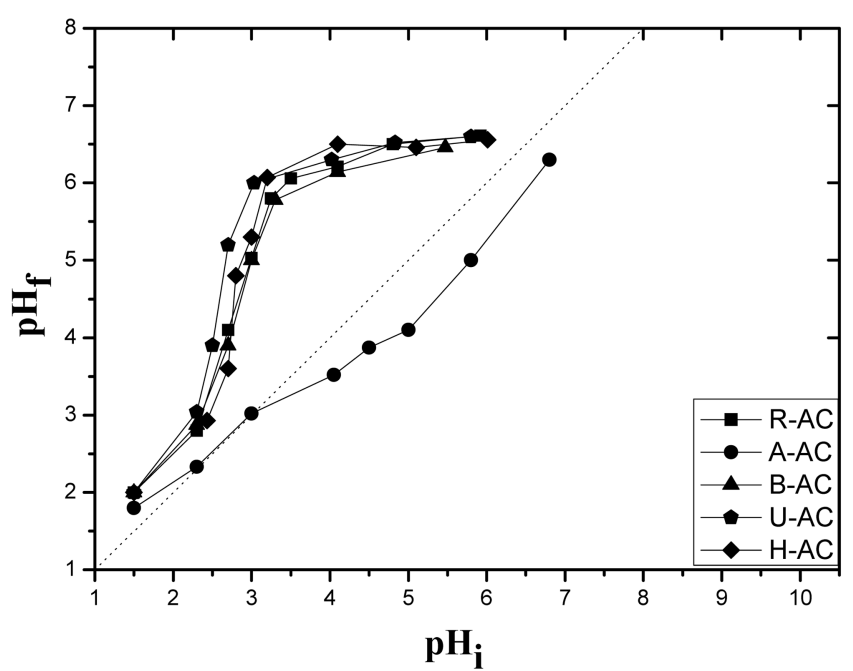

Fig. 7. The $\mathrm{pH}$ change of the solution before and after adsorption of copper ion on modified ACs. $\left(\mathrm{pH}_{\mathrm{i}}=\right.$ before adsorption, $\mathrm{pH}_{\mathrm{f}}=$ after adsorption) 


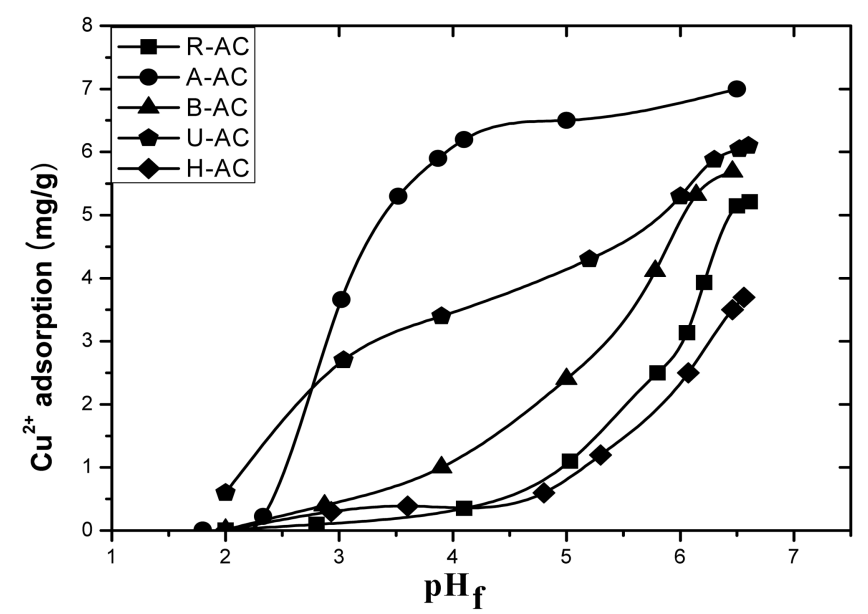

Fig. 8. Adsorption of copper ion as a function of $\mathrm{pH}_{\mathrm{f}}$ on modified ACs.

$\mathrm{pH}$ in Fig. 8. The adsorption capacities of copper ion increased as the increase of $\mathrm{pH}$ from 2 to 6.5 , because the increase of negatively charged sites and the decrease of positively charged sites which favored the adsorption of copper ion, but the curve shapes were different from each other. The adsorption capacities of copper ion on R-AC increased slightly from 0 to $1.1 \mathrm{mg} / \mathrm{g}$ until $\mathrm{pH} \mathrm{5}$, and rapidly increased to $5.15 \mathrm{mg} / \mathrm{g}$ until $\mathrm{pH} 6.5$. B-AC and $\mathrm{H}-\mathrm{AC}$ were shown similar trend of curve shapes to R-AC. But on A-AC, the adsorption capacities of copper ion increased rapidly from $\mathrm{pH} 2.3$ to 4 then slightly increased until $\mathrm{pH}$ 6.5. The $\mathrm{pH}_{\text {IEP }}$ of A-AC was $\mathrm{pH} 2.4$, so the surface of A-AC was negatively charged which favored the adsorption of copper ion. The $\mathrm{pH}_{\mathrm{IEP}}$ of other samples were $\mathrm{pH} 4.8,6.3,6.0$ and 8.6, so they were less favored the copper ion adsorption than A-AC. In case of U-AC, although the $\mathrm{pH}_{\text {IEP }}$ was more basic and zeta-potentials were lower than $\mathrm{R}-\mathrm{AC}$ in the entire $\mathrm{pH}$ region, the adsorption capacities of copper ion were larger than $\mathrm{R}-\mathrm{AC}$ in the entire $\mathrm{pH}$ region. Furthermore, the adsorption capacities of copper ion were larger than $\mathrm{A}-\mathrm{AC}$ in below $\mathrm{pH}$ 3. Yantasee et al. [19] reported that nitrogen functional groups such $\mathrm{NH}_{2}$ adsorbed the metal ions through not only ion-exchange process but also coordination process.

\section{Conclusions}

The results presented in this paper clearly showed the importance of zeta-potential of carbon adsorbents for removal of metal ion from aqueous solution. The structural properties of ACs were not so much changed by modification using $\mathrm{HNO}_{3}, \mathrm{NaOH}$ and $\mathrm{CO}\left(\mathrm{NH}_{2}\right)_{2}$, while the surface chemistry and zeta-potential were considerably changed. The $\mathrm{HNO}_{3}$ treated $\mathrm{AC}$ showed the largest copper ion adsorption capacities compare with other $4 \mathrm{ACs}$ in the range of
$\mathrm{pH} 3 \sim 6.5$, because the zeta-potential of this $\mathrm{AC}$ was the most negative than other $\mathrm{ACs}$ in the entire $\mathrm{pH}$ region, and the $\mathrm{pH}_{\mathrm{IEP}}$ was shifted from $\mathrm{pH} 4.8$ to $\mathrm{pH} 2.6$. In case of the $\mathrm{CO}\left(\mathrm{NH}_{2}\right)_{2}$ treated $\mathrm{AC}$, copper ion adsorption was larger than the as-received $\mathrm{AC}$ from $\mathrm{pH} 2$ to $\mathrm{pH} 6.5$ even though the $\mathrm{pH}_{\text {IEP }}$ was shifted to $\mathrm{pH} 6.0$, it was due to the coordination process operated between nitrogen functional groups and copper ion, but the copper ion adsorption increased as the solution $\mathrm{pH}$ increased and closed to $\mathrm{pH}_{\mathrm{IEP}}$

\section{Acknowledgements}

This research was financially supported by the Ministry of Commerce, Industry and Energy (MOCIE) and Korea Industrial Technology Foundation (KOTEF) through the Human Resource Training Project for Regional Innovation. We would also like to acknowledge the financially support of Korea Institute of Energy Research (KIER).

\section{References}

[1] Shim, J. W.; Park S. J.; Ryu, S. K. Carbon, 2001, 39, 1635.

[2] Babel, S.; Kurniawan, T. A. Chemosphere, 2004, 54, 951.

[3] Chen, J. P.; Wu, S. Langmuir, 2004, 20, 2233.

[4] Wang. S.; Lu, G. Q. Carbon, 1998, 36, 283.

[5] Xiao, B.; Thomas, K. M. Langmuir, 2005, 21, 3892.

[6] Strelko, Jr. V.; Malik, D. J. J. Colloid Interface Sci, 2000, 250, 213.

[7] Biniak, S.; Pakula, M.; Szymanski, G. S.; Swiatkowski, A. Langmuir, 1999, 15, 6117.

[8] Jia, Y. F.; Xiao, B.; Thomas, K. M. Langmuir, 2002, 18, 470.

[9] Adib, F.; Bagreev, A.; Bandoz, T. J. Langmuir, 2002, 16, 1980.

[10] Chingombe, P.; Saha, B.; Wakeman, R. J. Carbon, 2005, 43, 3132.

[11] Menendez, J. A.; Illan-Gomez, M. J.; Leon Y Leon, C. A.; Radovic, L. R. Carbon, 1995, 33, 1655.

[12] Corapcioglu, M. O.; Huang, C. P. Carbon, 1987, 25, 569.

[13] Wu, S. F.; Yanagisawa, K.; Nishizawa, T. Carbon, 2001, 39, 1537.

[14] Wu, S. F.; Yanagisawa, K.; Nishizawa, T. International Symposium of Carbon Tokyo, Japan, 1998, 72.

[15] Garcia, A. B.; Cuesta, A.; Montes-Moran, M. A.; Martinez-Alonso, A.; Tascon, J. M. D. J. Colloid Interface Sci. 1997, 192, 363.

[16] Menendez, J. A.; Phillips, J.; Xia, B.; Radovic, L. R. Langmuir, 1996, 12, 4404.

[17] Lu, C.; Chiu, H.; Lui, C. Ind. Eng. Chem. Res., 2006, 45, 2850.

[18] Harry, I. D.; Saha, B.; Cumming, I. W. J. Colloid Interface Sci, 2006, 304, 9.

[19] Yantasee, W.; Lin, Y.; Fryxell, G. E.; Alford, K. L.; Busche, B. J.; Johnson, C. D. Ind. Eng. Chem. Res., 2004, 43, 2759. 